\title{
ECO-INNOVATION FINANCING AS AN ELEMENT OF A "GREEN" ECONOMY FORMATION IN THE GLOBALIZATION CONDITIONS OF SUSTAINABLE DEVELOPMENT
}

\author{
Nataliia Goncharenko', Vladyslav Shapoval'
}

\begin{abstract}
The purpose of the paper is to substantiate the necessity for eco-innovation supporting and provide the scientific and practical recommendations for improving eco-innovation public and private financing in the globalizing conditions of sustainable development. Methodology. In the paper, eco-innovations are considered as new technologies, new ways of organizing production and social programs that ensure the movement of society in line with the principles of the theory of sustainable development and the interaction between economic development and environmental preservation, to a greater extent due to the production of additional interrelated internal and external effects. The survey is based on the modern methods of scientific research, in particular, general and special methods of analysis of economic phenomena and processes: historical-logical method; comparative analysis; structural-comparative and graphic analysis; structural-factor analysis (to analyze the impact of environmental factors on economic development and determine the relationship between environmental indices, individual factors and GDP growth rates); correlation-regression analysis (to model the impact of environmental factors on the economic development of the world); scenario approach (to substantiate the priority areas of development of greening of the global economic space); methods of logical analysis, abstract and cognitive modeling. The results of the survey showed that along with the existing problems, there is significant potential for green financing scaling up. The study identified problems that limit the development of eco-innovation financing, which include both problems typical for "green" projects (for example, the lack of a clear definition of the term "green"), and problems typical for the financial sector as a whole (for example, underdeveloped capital markets or discrepancy in financing terms). Scientific and practical recommendations for capital attraction stimulating and the development of eco-innovation financing in the context of world economy sustainable development are proposed. It is substantiated that the main condition for the mobilization of "green" investments from the private sector is a combination of public funding, regulation and participation of private market actors in an effective public-private partnership. Practical implications. The analysis of the peculiarities of the eco-innovation financing allows to determine the impact of public financial instruments on the acceleration and increase of the effect from private financing for "green" investment. The main advantages of introducing and tracking eco-innovations in the global economic system are identified. The conclusion is made about the positive impact of the use of environmental and energy efficient technologies on the level of economic development, investment attractiveness and competitiveness of the country. Value/originality. The provided theoretical bases and practical recommendations consider current trends and conditions for sustainable development of the developed and developing countries economies, may be used by the governments of countries to develop policies towards effective environmental natural resources use and formate an environmental management system in the global economic development greening process, and are the basis for the formation of an ecological and economic model of the country's development.
\end{abstract}

Key words: clean energy technologies, eco-innovations, green energy, green financing, green investments, green technologies, sustainable development.

JEL Classification: F55, 013, O44, O57, P51, Q56

\footnotetext{
Corresponding author

${ }^{1}$ V.N. Karazin Kharkiv National University, Ukraine.

E-mail: n.i.goncharenko@karazin.ua

ORCID: https://orcid.org/0000-0003-4148-5369

${ }^{2}$ V.N. Karazin Kharkiv National University, Ukraine.

E-mail: vlad-shapoval-99@ukr.net

ORCID: https://orcid.org/0000-0003-2075-1234
} 


\section{Introduction}

Environmental processes in a globalized space significantly transform international economic relations, enhancing the interaction of subjects. Better management of natural resources and improved environmental sustainability are among the main prerequisites for economic growth and social progress (Los \& Terletsky, 2013; Egorova, 2014).

Environmental innovations, (eco-technologies) include: technologies aimed at increasing energy efficiency, optimizing waste recycling, developments in the field of renewable energy, green construction, ecological transport, resource and waste management, and recycling of materials (Babenko et al., 2020). Environmental construction methods and building materials (including specialized mechanical engineering, the formation of a market for environmental products and environmental services); alternative transport, logistics and including a wide range of innovations, united by one common feature: their application should simultaneously form positive economic and environmental effects, should help prevent the emergence of social and environmental problems and reduce government costs to eliminate the consequences of technological progress.

Environmental innovations (or eco-innovations) representing new products, new technologies, new ways of organizing production and social programs that provide interaction between economic development and environmental preservation, the movement of society in line with the principles of the theory of sustainable development.

For high-tech industries such as renewable energy, alternative transport, environmental innovations require active government involvement. This is due to the long-term effect of such investments and impressive amounts. State measures in this case include direct and indirect investments.

Around the world, there is increasing attention to improving the financial system's ability to mobilize private capital for green investment and to manage the risks of climate change. This has led to increased international cooperation on "green" finance. There are a number of global and national initiatives and alliances that aim to foster policy dialogue, raise awareness, track progress, and develop norms and standards for "green" finance (Pavlova, 2014).

The development and functioning of alternative energy and, in particular, eco-innovations are devoted to the work by such foreign scientists as
E. Aberg, E. Bianco, A. Crowley, G. Escamilla, D. Gielen, R. Gorini. Considerable attention is paid to the development of eco-innovation in their works by such Ukrainian scientists as Goncharenko N. (2021, 2020), Dovgal O. (2021, 2020), Reshetnyak O. (2021), Dovgal G. (2021), Danko N. (2021), Shuba T. (2020), Babenko V. (2020), Rayevnyeva O. (2020), Zherlitsyn D. (2020), Chernyak O. (2015), Farenyuk J. (2015).

Despite the significant contribution of scientists to the research of environmental innovation, it should be noted that environmental innovation affects the economy as a factor, which makes it possible to increase the competitiveness of a region or country in the international arena. In turn, environmental innovation is becoming a determining factor in the sustainable development of an innovative economy.

Researchers and practitioners view innovation as the result of long-term projects that include research and testing phases. Technological innovations are of great importance for commercial organizations, while, with regard to fundamental scientific ideas, only a few of them are successfully implemented and commercialized, which determines the relevance and necessity for further work in this direction.

The purpose of the paper is to substantiate the necessity for eco-innovation supporting and provide the scientific and practical recommendations for eco-innovation public and private financing improving in the globalizing conditions of sustainable development.

\section{2. "Green" financing necessity}

One of the key aspects of economic policy in the field of environmental management is the financing and reimbursement of the costs of environmental pollution. Green finance is an emerging but rapidly growing segment of the financial market. The impetus for strengthening the role of the financial sector in supporting sustainable development and tackling climate change was given by the G20 and then reinforced by the Financial Stability Board and the Paris Agreement and related nationally determined contributions. While some progress has been made in the area of green finance, only a small proportion of bank loans can be clearly categorized as green according to national definitions. Less than $1 \%$ of bonds globally are labeled green, while less than $1 \%$ of institutional investment worldwide is classified as green 
infrastructure assets. An estimated 155.5 billion USD mobilized through green bonds in 2017, with 164.7 billion USD in green loans from banks 2014 (IFC, 2017).

The term "green finance" is generally used to refer to a broader phenomenon than climate finance, as it encompasses other challenges and risks associated with the environment. Green finance encompasses a wide range of financial institutions and asset classes, and includes both public and private funding (Dovgal et al., 2020).

In 2019 the global budget for R\&D in the field of public energy reached about 30.8 billion USD, which confirms the upward trend since 2017 after several years of decline (IEA, 2020a). Growth was largely supported by Europe and the United States, while government spending on $\mathrm{R} \& \mathrm{D}$ stabilized in China after two years of strong growth and ahead of the country's next five-year plan. By our calculation the average annual growth of public spending on $\mathrm{R} \& \mathrm{D}$ in China is 0.4514 billion USD $\left(\mathrm{R}^{2}=0.71\right)$, in the EU is 0.2657 billion USD $\left(\mathrm{R}^{2}=0.58\right)$, in the Americas is 0.2571 billion USD $\left(\mathrm{R}^{2}=0.75\right)$.

Over the last 40 years, IEA member countries' investments in energy $R \& D$ have gradually become more diversified. Nuclear energy, which has dominated global public R\&D spending since 1974 and accounted for $75 \%$ of the total state R\&D budget, fell to $21 \%$ in 2019 . Nuclear power, dominant in 1974 with $75 \%$ of total public energy $\mathrm{RD} \& \mathrm{D}$ budget, witnessed year- to-year reductions to reach $21 \%$ in 2019 , a share comparable to energy efficiency ( $21 \%)$, renewables (15\%) and cross-cutting RD\&D (23\%). R\&D budgets for fossil fuels, which were highest in the 1980s - early 1990s, but each year R\&D expenditures decrease - in 2013 (15\%), 9\% in 2019. According to this indicator, the leaders are Norway (1.7), Finland (0.81), Switzerland (0.56), and France (0.51) (IEA, 2019a).

Technological innovation is widely recognized as critical to addressing climate change and energy policy goals, including increasing access to energy and reducing air pollution. However, tracking innovation progress is a challenge. The relationship between the resources invested - finance and skills - and the intermediate results - patents and products - is sometimes unclear. Components such as cheaper technologies, industrial transformation and economic growth are difficult to measure or relate to inputs. Nevertheless, a number of indicators can shed light on clean energy innovations around the world, including funding and patenting (IEA, 2020b) (Figure 1).

\section{Global investments dynamics in the new energy sector}

According to the analysis of the International Renewable Energy Agency (IRENA), foreign direct investment in renewable energy sources accounted for about $2 \%$ of total direct investment in 2018. Combined efforts are needed to increase the scale of capital. Policies can implement

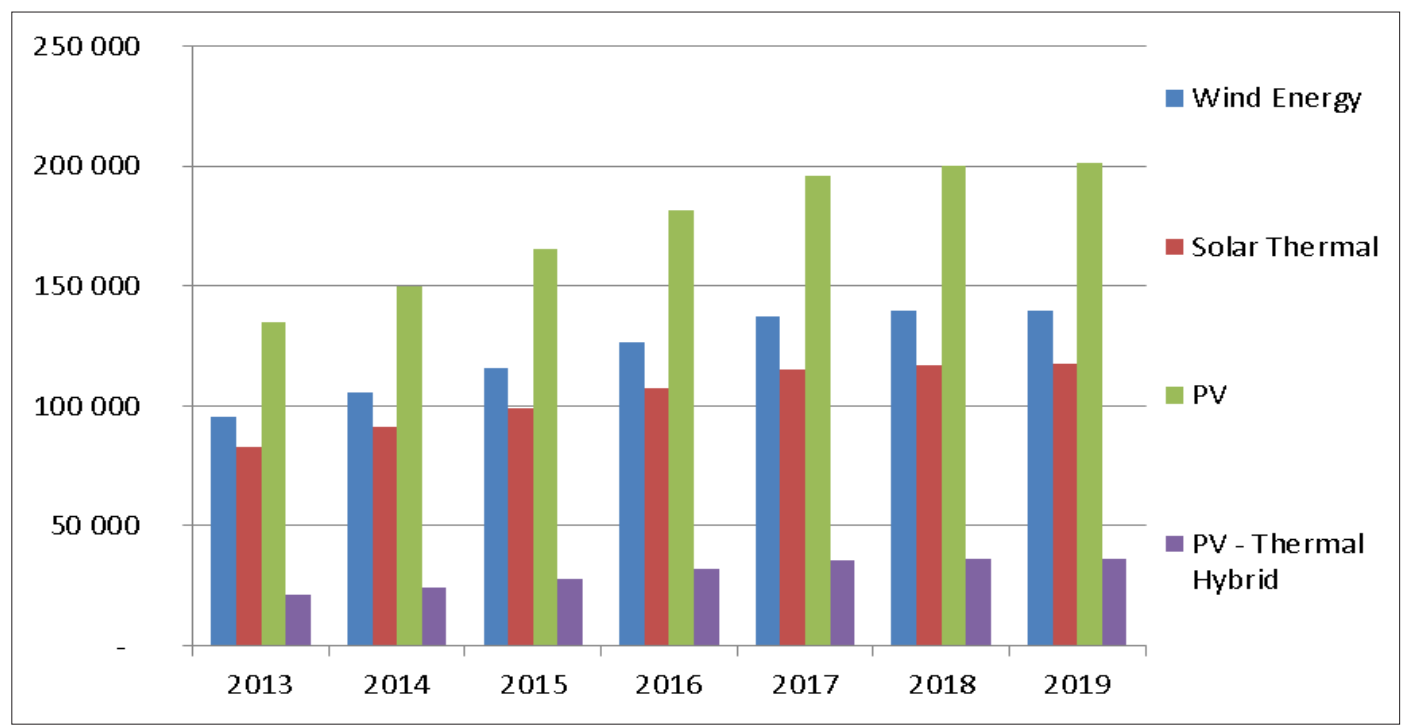

Figure 1. Global number of patents in wind and solar generation, 2013-2019

Source: (International Renewable Energy Agency, 2019) 
a favorable framework to increase investment in renewable energy and reduce specific barriers faced by investors. Consider investment in renewable energy by developed and developing countries (International Renewable Energy Agency, 2018).

Global corporate R\&D spending in the energy sectors, in particular in the automotive industry, energy and grid, and renewable energy tends to increase. The average annual growth of corporate $R \& D$ expenditures in the automotive -1.161 billion USD, the probability of the forecast is $97.89 \%$. The average annual growth in electricity generation and network -0.489 billion USD, the probability of the forecast is $85.95 \%$. The average annual growth of corporate expenditures in renewable energy -0.272 billion USD, the probability is $89.71 \%$ (Figure 2).

The analysis reflects the growing trend of investment in alternative energy. The average annual growth of investment in these regions is: in the Asia-Pacific region - 3.981 billion USD $\left(\mathrm{R}^{2}=0.92\right)$, in the Americas - 4.520 billion USD $\left(\mathrm{R}^{2}=0.89\right)$, Europe, Middle East, Africa 2.675 billion USD $\left(\mathrm{R}^{2}=0.85\right)$ (Figure 3$)$. The speed and scale of the decline in energy investment activity in the first half of 2020 is unprecedented. Many companies restrained their costs; project workers were locked home; the planned investments have been deferred; supply chains are interrupted.

Commercial financial institutions continued to make a significant contribution, averaging 25\% of total private funding in 2017-2018 (Figure 4).
This category includes commercial and investment banks, which mainly lend at market rates at the level of projects on mature technologies such as solar and wind turbines. In 2018 solar and wind (terrestrial) power plants received 21 billion USD from commercial financial institutions and 22 billion USD respectively, and offshore wind turbines - 14 billion USD. In recent years, energy-producing corporate entities have played a significant role in the private financing of renewable energy sources, providing an average of 17 billion USD for the year in 2017-2018 (IEA, 2020 b). In 2017-2018, 33\% of all projects were in East Asia and the Pacific, while 30\% were in the United States and 17\% in Western Europe. However, for the three regions there is one characteristic feature of investments: they have been mainly domestic and focused on solar and wind energy.

In our opinion, the potential for private investment is largely unrealized. Activation of capital in the markets for renewable energy is an important factor for the growing demand for green energy and infrastructure to ensure sustainable economic development. Larger institutional investments in renewable energy can create a positive feedback loop by increasing the capital invested in this sector. This would reduce the cost of financing the sector as a whole, thus helping attract other sources of capital (Goncharenko, 2020).

International Development Banks have managed with the complex and extraordinary

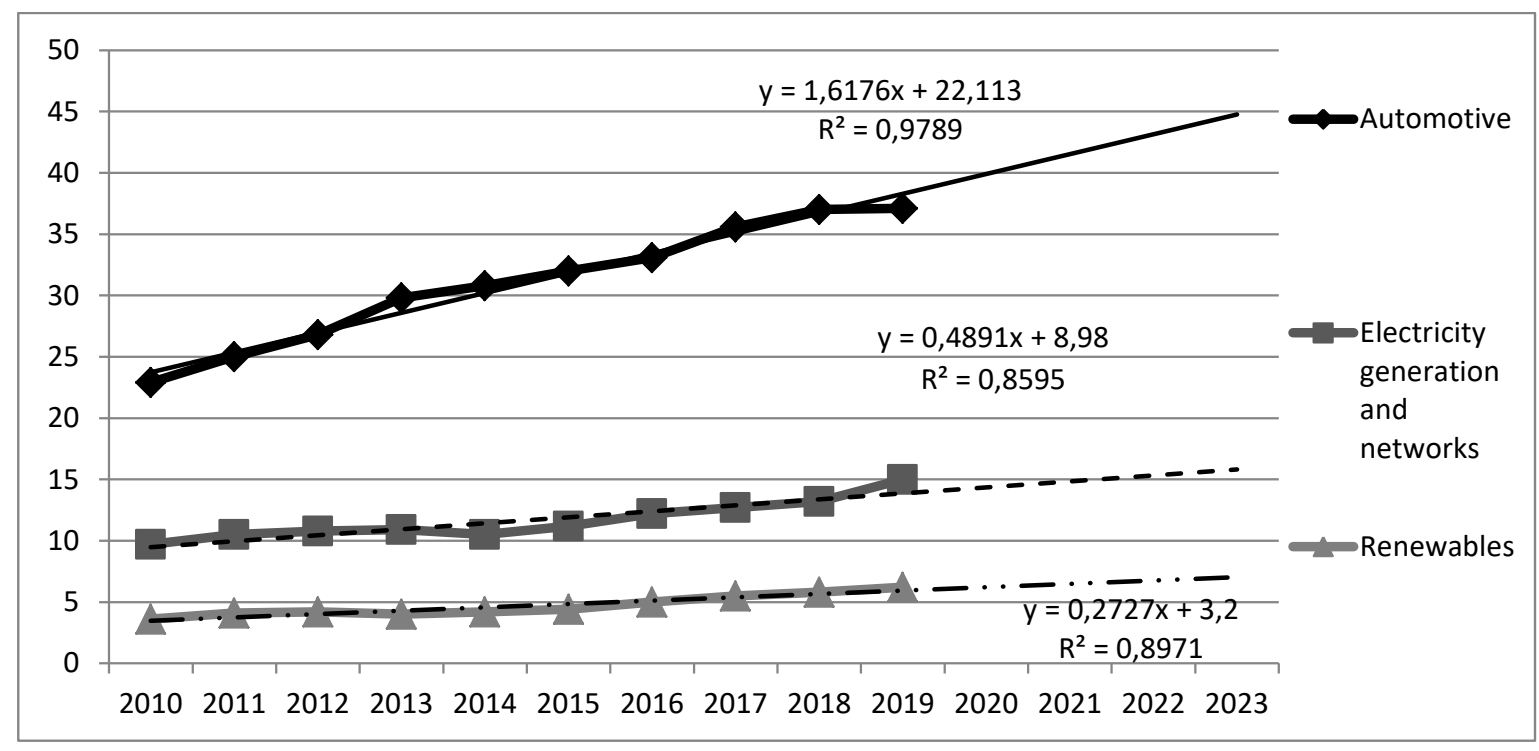

Figure 2. Global corporate R\&D expenditures in the energy sectors, 2010-2019, billion USD

Source: (IEA, 2019b) 
Vol. 2 No. 2, 2021

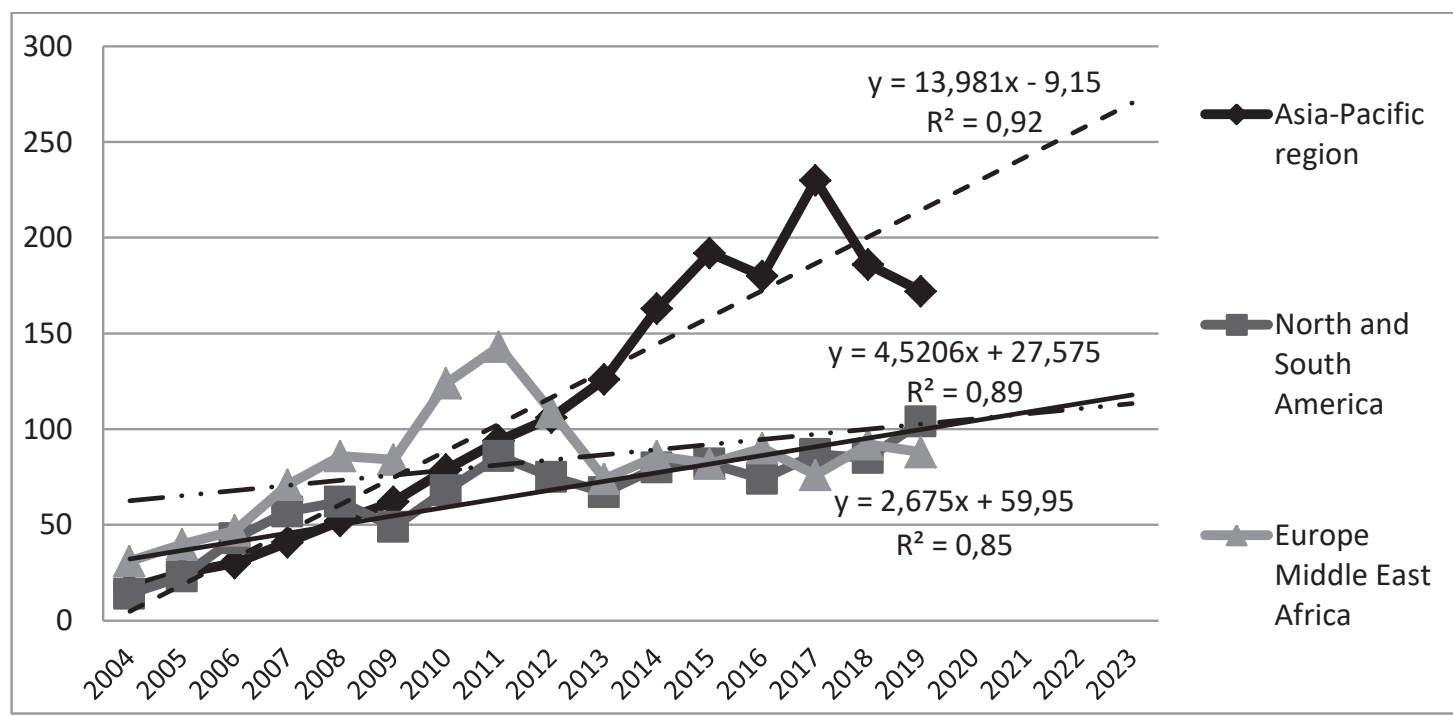

Figure 3. Global investments in renewable energy, 2004-2019 by major regions of the world, billion USD Source: (Statista, 2019)

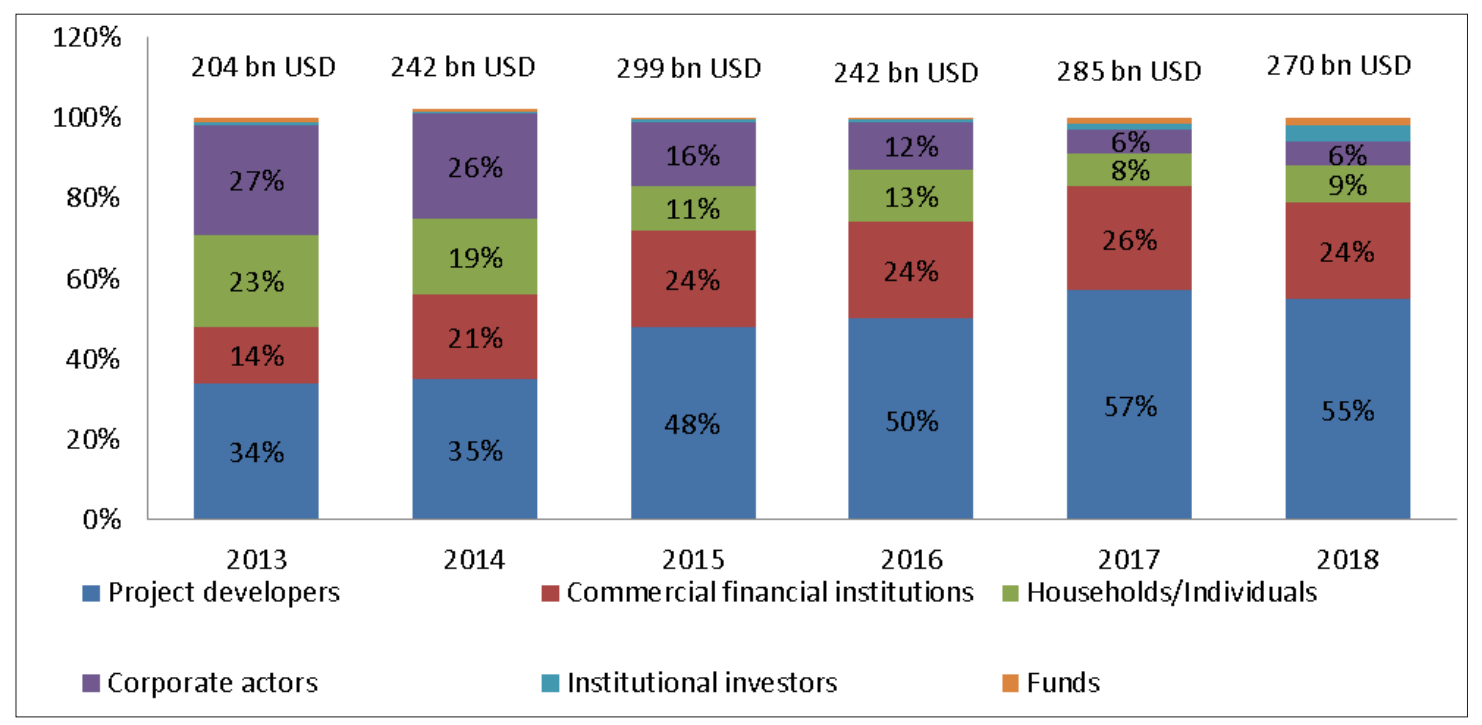

Figure 4. Global private investment in renewable energy by investment source, 2013-2018

Source: (International Renewable Energy Agency, 2020a)

Table 1

Engines for capital mobilization in renewable energy sources

\begin{tabular}{|c|l|}
\hline Sphere & \multicolumn{1}{c|}{ Explanation } \\
\hline Society & $\begin{array}{l}\text { Bring global capital in line with the goals of sustainable development and development } \\
- \text { Needs for investment in infrastructure and development } \\
- \text { The climate is investment-oriented }\end{array}$ \\
\hline Energy Sector & $\begin{array}{l}\text { Increase investment for energy transition, reduce the cost of capital for renewable energy } \\
- \text { Needs for investment in energy transition } \\
\text { - Reducing the cost of capital for renewable energy }\end{array}$ \\
\hline Institutional investors & $\begin{array}{l}\text { Achieve economic return, respond to social and regulatory changes } \\
- \text { Strong, long-term profitability, asset diversification, lower asset risk } \\
\text { - Fiduciary obligations, evolving social, policy and regulatory demands }\end{array}$ \\
\hline
\end{tabular}

Source: authors' based on materials of (International Renewable Energy Agency, 2020b) 
nature of "green" financing for projects, as well as the difficulties in raising capital for "green" investments. Firstly, they help governments remove the main constraint - insufficient knowledge of risk assessment and understanding of the benefits of greening. Feasibility assessment technical assistance usually precedes or forms part of the IBRD financing package. Secondly, the early-stage risks associated with green infrastructure projects are mitigated through improved governance structures, stakeholder engagement, regulation of the investment generation process, reduced project complexity, and private sector engagement by understanding priority drivers, sparking interest in "green" investment. IBRD also recommends to use a toolkit that includes methods for assessing the upward and downward risks of resource depletion or changes in the quality of the environment and ecosystems as a result of investments in a project (Khisamutdinov, 2012).

Obviously, due to the huge amount of capital, a foundation must be laid for the distribution of global capital into sustainable sectors of the economy. This foundation will provide an opportunity to attract more investment to reduce the risks associated with certain growing threats. Increase funding for the alternative sources sector, long-term investment and institutional capital, can also help reduce the sector's funding costs, making sustainable energy more affordable.

The COVID-19 pandemic has exposed the limitations of the current energy system and made it clear that a global energy transition is inevitable. Green incentive packages are a key opportunity to demonstrate to investors the government's long-term commitment to renewable energy, boosting their confidence and attracting additional investment in the sector. By focusing recovery plans on the energy transition, policymakers can use the socio-economic benefits to overcome the current economic downturn, including significant job benefits.

\section{Eco-innovation implementing advantages}

"Green" technologies provide companies with energy efficiency, a high level of social responsibility, which supports competitiveness, leadership and is reflected in the financial results and capitalization of companies. The state can only provide support in some cases by providing grants, subsidies, and other financial rewards.
The development of eco-innovations, like other innovative technologies, should contribute to increasing production efficiency, preventing negative impact on the environment and achieving environmental safety, which is understood as one of the components of national security, a set of natural, social, technical and other conditions that ensure the quality of life and safety. Life and activities of the population living in a given territory are of great importance.

The main benefits of implementing and tracking eco-innovation can be:

1) calculation and forecasting of the activities of organizations in the field of eco-innovation, consumer behavior, as well as the development of "cleaner" production;

2) identification of catalysts and barriers to the creation and implementation of eco-innovation necessary in the development of effective tax and trade policies;

3) raising awareness of environmental innovation among stakeholders and encouraging companies to be eco-innovative, based on a benefit analysis for companies, sectors and the economy;

4) helping communities break the link between economic growth and environmental pollution;

5) creating a need for ecological products and lifestyle.

It is advisable to invest in innovations, first of all, in infrastructure projects that give a multiplier effect for the economy (the cost of goods produced significantly exceeds investments, which means that inflation is decreasing). Infrastructure development is also one of the priorities for innovative development.

In the case when it comes to the development and implementation of eco-innovation, an important criterion is the provision of not only economic, but also sustainable socio-economic and ecological development. At present, we can talk about the lack of a universal toolkit that allows you to study innovative processes that have different environmental effects and reduce the negative impact on the environment, within various systems. An important aspect is the combination of a theoretical approach to the methodology for developing eco-innovations and assessing the effectiveness of their application with tools used in practice to measure innovation at the level of organizations, territorial entities and other economic systems. 


\section{Conclusions}

While there is significant potential for scaling up green finance, the development of this market faces a number of challenges. Challenges to the development of green finance include both those specific to green projects (for example, the lack of a clear definition of the term "green") and those specific to the financial sector as a whole (for example, underdeveloped capital markets or mismatch in terms of financing).

In a broader context, the main challenges slowing the development of "green" finance at the global and national levels include the following:

1) lack of strategic signals and mechanisms at the national level;

2) lack of a single definition of the term "green";

3) scattered methodologies for assessing the volume of green financing and the effect of green investments;

4) low awareness of green finance;

5) low potential of market participants in terms of assessing environmental and financial risks associated with projects underlying financing.

Raising capital requires ensuring that growing environmental concerns and climate change interventions are coupled with sustainable economic returns. Smart environmental projects help spread green technologies, reduce pollution and improve resource efficiency, and contribute to reducing greenhouse gas emissions. Governments in many countries are taking steps to stimulate green finance to mobilize the necessary resources to support economic transformation and remain competitive.

Additional funding from the public and private sectors will be required to ensure the transition to green infrastructure. Public policies and markets must also create opportunities for converging public and private finance. Private business finance can support investments in private assets such as factories and equipment. Private investors respond to private rather than social returns, so if price signals do not reflect social costs and benefits (for example, due to negative or positive externalities), incentives in the private sector will not match those in the public sector. Therefore, corrective pricing (such as a carbon tax that matches the social cost of such emissions) is necessary and effective in many cases to stimulate the required private investment. A key prerequisite for mobilizing green investment from the private sector is the combination of public funding, regulation and the participation of private market actors in effective public-private partnerships.

Green finance markets require sufficient regulatory incentives to stimulate more green projects. Business priorities often do not align with the social goal of sustainable development, exacerbating the problem of social exclusion and environmental degradation. An increased focus on promoting green and socially responsible production in resource-based industries can change behavior. There are examples of companies that are willing to work towards sustainable development, but lack effective contact points for engaging with the public sector. Around the world, various adjustments in the form of taxes and subsidies are used to stimulate business in accordance with social costs and benefits. Examples include tax deductions for investments in new (risky) technologies, feed-in tariffs for renewable energy, carbon payments, tobacco taxes, and investment and export guarantees or insurance. Countries that have a favorable regulatory and tax environment attract more green investors and tend to offer more financing options. Public policy should ensure that programs are encouraged and funded for development projects with minimal environmental impact and green infrastructure, including the provision of gratuitous technical assistance in the development of green projects.

Public financial instruments can accelerate and enhance the impact of private finance for green investments. Typical characteristics of green infrastructure finance include high upfront capital costs, long payback periods, and a high degree of dependence on regulatory frameworks (e.g. carbon charges). These features often increase the need for public sector funding. The public sector in general and public financial institutions in particular can help mobilize private resources by taking on risks that the private sector is not prepared for. Effective use of available risk mitigation tools is essential given their limited availability.

Countries where the development of green finance is a public policy priority are formulating national action plans or roadmaps to green the economy and the financial sector. These plans contain measures to assist the financial sector in financing green projects. National action plans help drive coherent and essential work between financial sector regulators and line ministries. For example, 
the development of criteria for green mortgages requires the direct involvement of government housing and construction agencies to ensure that standard requirements are adequate. China, France and Indonesia are examples of countries that have developed national strategies to green their financial systems.
Foundational components of successful experiences in greening the financial sector include: introduction of green finance principles; systems for monitoring compliance with the guidelines and tracking financial flows to green assets; methods for assessing the financial impacts of factors associated with climate change.

\section{References:}

Babenko, V., Rayevnyeva, O., Zherlitsyn, D., Dovgal, O., Goncharenko, N., \& Miroshnichenko, T. (2020). Dynamics of Forecasting the Development of Renewable Energy Technologies in Ukraine and Chile. IJIEPR, vol. 31, issue 4, pp. 587-596.

Chernyak, O., \& Farenyuk, J. (2015). Doslidzhennya obsyahiv investuvannya v «zelenu enerhetyku» [Research of investments in "green energy"]. The Journal of Kyiv National University Taras Shevchenko, vol. 12, pp. 59-67. (in Ukrainian)

Dovgal, O., Goncharenko, N., Reshetnyak, O., Dovgal, G., \& Danko, N. (2021). Priorities for Greening and Sustainable Development of OECD Member Countries and Ukraine: a Comparative Analysis. Comparative Economic Research. Central and Eastern Europe, vol. 24, no. 1, pp. 45-63. doi: 10.18778/ 1508-2008.24.03

Dovgal, O., Goncharenko, N., Reshetnyak, O., Dovgal, G., Danko, N., \& Shuba, T. (2020). Sustainable Ecological Development of the Global Economic System: the Institutional Aspect. Journal of Environmental Management and Tourism, vol. XI, issue 3(43), pp. 725-740. doi: https://doi.org/ $10.14505 / /$ jemt.v11.3(43).27

Egorova, M. S. (2014). Vliyaniye tekhnologii i tekhnologicheskikh izmeneniy na protsess stanovleniya "zelenoy ekonomiki" [Influence of technology and technological changes on the formation of a "green economy"]. Fundamental Research. Economic sciences, vol. 5, pp. 299-302. (in Ukrainian)

Goncharenko, N. (2020). Loan Financing of Global Business Transactions. Internationalization of the World Economy: Current Trends: monograph. E. Siskos, O. Rogach (Eds.). EVKONOMIA Publisher, Kastoria, pp. 125-139.

International Energy Agency (2019a). Total public energy RD\&D budgets per thousand units of GDP by country for 2019. Available at: https://www.iea.org/data-and-statistics/charts/total-public-energyrd-and-d-budgets-per-thousand-units-of-gdp-by-country-for-2019 (accessed 20 May 2021).

International Energy Agency (2019b). Global corporate R\&D spending in energy-related sectors. Available at: https://www.iea.org/data-and-statistics/charts/global-corporate-r-and-d-spending-inenergy-related-sectors-2010-2019 (accessed 18 May 2021).

International Energy Agency (2020a). Energy Technology RD\&D Budgets. Available at: https://www.iea.org/reports/energy-technology-rdd-budgets-2020\#global-energy-rdd-trends (accessed 20 May 2021).

International Energy Agency (2020b). Global status of clean energy innovation. Available at: https://www.iea.org/reports/clean-energy-innovation/global-status-of-clean-energy-innovation-in-2020 (accessed 20 May 2021).

International Finance Corporation. World Bank Group (2017). Galvanizing Green Finance: A Bottom-up Approach. Available at: https://www.ifc.org/wps/wcm/connect/news_ext_content/ifc external_corporate_site/news+and+events/news/galvanizing+green+finance+a+bottom-up+approach (accessed 15 May 20̄21).

International Renewable Energy Agency (2018). Opportunities to accelerate national energy transitions through advanced deployment of renewables. Available at: https://irena.org/-/media/Files/IRENA/ Agency/Publication/2018/Nov/IRENA_G20_Opportunities_2018.pdf (accessed 20 May 2021).

International Renewable Energy Agency (2019). RE technology patents reports. Available at: http://inspire.irena.org/Pages/patents/Patents-Search.aspx (accessed 20 May 2021).

International Renewable Energy Agency (2020a). Global landscape of Renewable energy Finance. Available at: https://irena.org/-/media/Files/IRENA/Agency/Publication/2020/Nov/IRENA_CPI_ Global_finance_2020.pdf (accessed 18 May 2021).

International Renewable Energy Agency (2020b). Mobilising Institutional Capital For Renewable Energy. Available at: https://www.irena.org/-/media/Files/IRENA/Agency/Publication/2020/Nov/ IRENA_Mobilising_Institutional_Capital_2020.pdf(accessed 20 May 2021). 
Khisamutdinov, I. A., \& Karachurina, G. G. (2012). Ekoinnovatsii kak faktor v dostizhenii novogo kachestva ekonomicheskogo rosta [Eco-innovation as a factor in achieving a new quality of economic growth]. International technical and economic journal, vol. 4, pp. 64-67. (in Russian)

Los, L. V., \& Terletsky, M. D. (2013). Perspektyvna alternatyvna enerhetyka [Promising alternative energy]. The Journal of Zhytomyr National Agroecological University, vol. 1(1), pp. 203-214. (in Ukrainian) Pavlova, E. I. (2014). Ekoinnovatsii kak faktor ustoychivogo razvitiya ekonomiki i otsenka ikh urovnya [Eco-innovation as a factor in sustainable economic development and assessment of their level]. Creative Economy, vol. 2(86), pp. 46-52.

Statista (2019). New investment in clean energy worldwide from 2004 to 2019, by major region. Available at: https://www.statista.com/statistics/661252/worldwide-new-investment-in-sustainableenergy-by-region/ (accessed 20 May 2021). 